\title{
Effect of Mineral Fertilization and Sowing Rate on Chemical Composition of Two Linseed Cultivars
}

\author{
Klimek-Kopyra A. ${ }^{1}$, Zając T. ${ }^{1}$, Micek P. ${ }^{2}$, Borowiec F. ${ }^{2}$ \\ ${ }^{1}$ Instytut of Plant Production, Poland \\ ${ }^{2}$ Department of Animal Nutrition Agricultural University of Cracow, Poland \\ Correspondence: Klimek-Kopyra A., Instytut of Plant Production, Poland. E-mail: aklimek@ar.krakow.pl
}

Received: January 19, 2012 Accepted: February 11, 2012 Online Published: December 13, 2012

doi:10.5539/jas.v5n1p224

URL: http://dx.doi.org/10.5539/jas.v5n1p224

\begin{abstract}
The objective of the experiment was to determine the effect of two levels of mineral fertilization ( 90 and $180 \mathrm{~kg}$ $\mathrm{NPK} / \mathrm{ha}$ ) and three sowing rates (300, 600 and 900 germinating seeds per $\left.1 \mathrm{~m}^{2}\right)$ on chemical composition of two linseed cultivars (Opal and Hungarian Gold) differing in seed colour. Basic chemical composition, fatty acid profile, amino acid composition and yields of the seeds were determined. The yields of protein and fat were also estimated. Seeds of these two studied cultivars did not show any significant differences in chemical composition after the application of different agro-technologies. Regardless of the cultivation factors, cv. Opal had higher $\mathrm{NDF}$ and ADF contents and over twice higher content of ADL (40.3 vs. $19.9 \mathrm{~g} / \mathrm{kg} \mathrm{DM} ; \mathrm{P}<0.05)$. Increased mineral fertilization caused an increase in the content of amino acids, especially glutamine, arginine and asparagine, in seeds. Fatty acid profile in seed oil did not show significant changes as a result of the cultivation factors applied.
\end{abstract}

Keywords: linseed, chemical composition, amino acids, fatty acid profile, cultivars, mineral fertilization, sowing rate

\section{Introduction}

In Europe climatic and soil conditions the most recommended oil plants for cultivation are winter rape, oilseed sunflower and linseed (Diepenbrock, 2001). Linseed provides seeds rich in polyunsaturated fatty acids, especially in $\alpha$-linolenic acid, which are used for consumption, animal nutrition and in industry. When added to animal rations, linseed may modify the fatty acid profile of their tissues (Barowicz, 1998). Borowiec et al. (2001) showed that commercial varieties of linseed differ in the nutrient content as well as in the fatty acid profile of seeds. Both yellow- and brown-seeded cultivars have a similar fatty acids profile which is modified by agroclimatic conditions only to a small extent (Froment et al., 1998; Zając et al., 2001). Linola, a solin type of linseed that was developed in the 1990s, has a low content of $\alpha$-linolenic acid in the oil (Dribnenki et al., 1999).

Linseed cultivars are characterized by a high variation of the seed yield depending on the cultivation area, agroclimatic conditions and cultivation technology (Candrakova \& Bakula, 2001; Saeidi \& Rowland, 1999). The most frequently studied factor of cultivation has been the sowing rate (Casa et al., 1999; Zubal, 2001; Hassan \& Leitch, 2000), which ranged from 200 to 1200 germinating seeds per $1 \mathrm{~m}^{2}$. However, when sowing rate was considered as an individual factor, it has had little effect on the yield of linseed. Therefore the optimum sowing rate should be decreased to $500-700$ seeds per $\mathrm{m}^{2}$.

The mineral fertilization applied in the cultivation varies widely according to specific economic and organizational structure and soil conditions (Hasan \& Leitch, 2000; Candrakova \& Bakula, 2001; Grant et al., 1999; Hocking, 1995). Currently in Poland about $86 \mathrm{~kg}$ NPK is applied per hectare of linseed plantation. This has encouraged us to conduct research with a higher level of mineral fertilization and to determine the qualitative and quantitative reaction of linseed varieties to that factor. The objective of the present experiment was to assess the effects of different levels of mineral fertilization and different sowing rates on chemical composition as well as amino acids and fatty acids profile of two linseed cultivars (Opal and Hungarian Gold). 


\section{Material and Methods}

In years 2000-2002, a three-factorial field experiment was carried out with two linseed cultivars: Opal (Polish brown-seed variety) and Hungarian Gold (HG, Hungarian yellow-seeded variety). Linseed cultivar was the first experimental factor. The second factor were sowing rates (300, 600 or 900 germinating seeds per $\left.1 \mathrm{~m}^{2}\right)$ and the third one level of mineral fertilization ( 90 or $180 \mathrm{~kg} \mathrm{NPK} / \mathrm{ha}$ ). The experiment was arranged in a random block design in four replications, with experimental plot size of $10 \mathrm{~m}^{2}$ on degraded chernozem developed from loess. Medium early potatoes, grown without manure, were used as a forecrop of linseed. Fertilizers were used at a rate of $24 \mathrm{~kg} \mathrm{P} \mathrm{O}_{5} / \mathrm{ha}, 36 \mathrm{~kg} \mathrm{~K} 2 \mathrm{O} / \mathrm{ha}$ and $30 \mathrm{~kg} \mathrm{~N} / \mathrm{ha}$ in the form of ammonium nitrate (90 kg NPK in total) prior to sowing. At the same time, on the other plots $180 \mathrm{~kg}$ of NPK $\left(48 \mathrm{~kg} \mathrm{P}_{2} \mathrm{O}_{5} / \mathrm{ha}, 72 \mathrm{~kg} \mathrm{~K}{ }_{2} \mathrm{O} / \mathrm{ha}\right.$ and $30 \mathrm{~kg} \mathrm{~N} / \mathrm{ha}$ prior to sowing and $30 \mathrm{~kg} \mathrm{~N} / \mathrm{ha}$ in the vegetative phase at $9 \mathrm{~cm}$ of plant height) was applied. Seeds were sown at a depth of $2 \mathrm{~cm}$, with row spacing of $15 \mathrm{~cm}$. Pre-sowing treatments were performed according to standard principles of cultivation. In the vegetative phase, dicotyledonous and monocotyledonous weeds were treated with herbicides Chiesel 75 WG and Targa Super EC. In the year 2000, the emergence of linseed was followed by flea beetle control using Karate $025 \mathrm{EC}$ at a rate of 0.31 per 1 ha. In the year 2002 disturbances were observed during the germination and emergence phase of the sown linseeds, resulting from violent, storm-related rainfalls. This forced us to exclude two field replications from the analysis of experimental results. The linseed was harvested at the end of the second and the beginning of the third decade of August, after previous desiccation with Reglone 200 SL. Harvest was performed with a Seedmaster plot combine.

Chemical composition of seeds was determined according to AOAC (1995) methods. Neutral detergent fibre (NDF), acid detergent fibre (ADF) and acid detergent lignin (ADL) were determined by the method of Goering and Van Soest (1970). Fatty acid profile of linseed fat was analysed using gas chromatography (Varian Star 3400 CX; detector FID, argon as a carrier gas; column DB-FFAP). Amino acids were determined using an AAA-400 analyser (INGOS, Czech Republic) after hydrolysis with $6 \mathrm{~N} \mathrm{HCL}\left(110^{\circ} \mathrm{C}, 24 \mathrm{~h}\right)$. Sulphur-containing amino acids were assayed after oxidation with performic acid. The data were subjected to the three-way analysis of variance using the GLM procedure of SAS (1995). The individual means for sowing rate were separated by Duncan test (SAS 1995). Differences were considered to be significant at $\mathrm{P}<0.05$.

\section{Results and Discussion}

Chemical composition of the investigated linseed varieties is shown in Table 1. Neither the linseed cultivar nor the amount of sown seeds had a significant $(\mathrm{P}>0.05)$ effect on the contents of ash, protein, fat and $\mathrm{N}$-free extractives in the seeds. The average content of these components was similar to the values reported by other Polish authors (Borowiec et al., 2001; Zając et al., 2001). Results of chemical analyses of yellow-seeded linseed cv. Royal (Spain) differ in their higher content of protein and lower content of fibre and its fractions (Treviño et al., 2000). Regardless of the sowing rate and fertilization level, cv. Opal was characterized by higher contents of both crude fibre and NDF ( $>0.05)$. Compared to cv. HG, cv. Opal was found to contain more ADF (117 vs. 96 $\mathrm{g} / \mathrm{kg} \mathrm{DM} ; \mathrm{P}<0.05)$ and over twice more ADL (40.3 vs. $19.9 \mathrm{~g} / \mathrm{kg} \mathrm{DM} ; \mathrm{P}<0.05)$ which are the most undegradable fractions of fibre. The content of these components was also influenced by the sowing rate. Seeds from plants sown at a rate of $600 \mathrm{pcs} / \mathrm{sqm}$ were characterized by the highest contents of both fibre and its fractions.

Increasing the mineral fertilization from 90 to $180 \mathrm{~kg} \mathrm{NPK} / \mathrm{ha}$ only slightly influenced the content of fibre and its fractions and the contents of fat and $\mathrm{N}$-free extractives $(\mathrm{P}>0.05)$. However, the elevated fertilization level had a significant effect on increasing the protein content from 205 to $220 \mathrm{~g} / \mathrm{kg} \mathrm{DM}(\mathrm{P}<0.05)$.

Regardless of the cultivation factors, significant differences were found in fatty acid profile between the linseed cultivars studied (Table 2). Cv. HG was characterized by a higher content of $\mathrm{C}_{18: 1}$ and $\mathrm{C}_{18: 2}$ acids and a lower content of $\mathrm{C}_{18: 3}$, which in turn led to a higher sum of unsaturated fatty acids in this cultivar $(\mathrm{P}<0.05)$. On the other hand cv. Opal showed a higher content of fatty acids $\mathrm{C}_{16: 0}$ and $\mathrm{C}_{18: 0}(\mathrm{P}<0.05)$. Likewise, increased mineral fertilization of linseed caused a statistically significant increase only in the content of $\mathrm{C}_{16: 0}$ acid in oil $(\mathrm{P}<0.05)$. In addition, increased content of $\mathrm{C}_{18: 1}$ and decreased content of $\mathrm{C}_{18: 3}$ were found in the seeds following higher nitrogen fertilization $(\mathrm{P}>0.05)$. Mean percentages of individual fatty acids, calculated irrespective of the compared cultivation factors, indicate a similar range of variations and are convergent with the findings of Borowiec et al. (2001) or Froment et al. (1998). Although the content of oleic acid slightly exceeded the values reported by Froment et al. (1998). 
Table 1. Chemical composition of linseed cultivars in relation to sowing rate and mineral fertilization (means from 3 years)

\begin{tabular}{lcccccccccc}
\hline \multirow{2}{*}{ Effect $^{1}$} & \multirow{2}{*}{ Item } & \multirow{2}{*}{$D M(\mathrm{~g} / \mathrm{kg})$} & $A s h$ & $C P$ & $E E$ & $C F$ & $N F E$ & $\mathrm{NDF}$ & ADF & ADL \\
\cline { 4 - 11 } & & & & \multicolumn{7}{c}{$\mathrm{g} / \mathrm{kg} \mathrm{DM}$} \\
\hline Cultivars & - Opal & 958 & 38.6 & 211 & 444 & 65 & 243 & 281 & $117^{\mathrm{a}}$ & $40.3^{\mathrm{a}}$ \\
& $-\mathrm{HG}^{2}$ & 960 & 38.5 & 214 & 457 & 57 & 233 & 249 & $96^{\mathrm{b}}$ & $19.9^{\mathrm{b}}$ \\
Sowing & -300 & 958 & 38.6 & 210 & 450 & 58 & 243 & 266 & 100 & 27.8 \\
Rate & -600 & 960 & 38.5 & 215 & 451 & 66 & 230 & 286 & 116 & 34.0 \\
(pcs/sqm) & -900 & 959 & 38.6 & 213 & 450 & 58 & 241 & 241 & 104 & 28.5 \\
Mineral & -90 & 958 & 37.6 & $205^{\mathrm{b}}$ & 453 & 59 & 246 & 260 & 103 & 28.6 \\
fertilization & -180 & 959 & 38.6 & $220^{\mathrm{a}}$ & 448 & 63 & 230 & 270 & 111 & 31.6 \\
(kg NPK/ha) & & & & & & & & & & \\
SEM & & 0.23 & 0.20 & 0.25 & 0.35 & 0.25 & 0.40 & 0.88 & 0.41 & 0.25 \\
\hline
\end{tabular}

1 - three-way analysis of variance

2 - Hungarian Gold

a. b. -means with different letter are significantly different $(\mathrm{P}<0.05)$; means without index are not significantly different $(\mathrm{P}>0.05)$.

DM - dry matter; Ash - crude ash; CP - crude protein; EE - ether extract (crude fat); CF - crude fibre; NFE $\mathrm{N}$-free extractives; NDF - neutral detergent fraction, ADF - acid detergent fraction, ADL - acid detergent lignin

Table 2. Effect of cultivars, sowing rate and mineral fertilization on the fatty acid profile of linseed oil (\%; means from 3 years)

\begin{tabular}{lcccccccc}
\hline Effect $^{1}$ & Item & $C_{16: 0}$ & $C_{18: 0}$ & $C_{18: 1}$ & $C_{18: 2}$ & $C_{18: 3}$ & Others & Sum of unsaturated fatty acids \\
\hline Cultivars & - Opal & $7.2^{\mathrm{a}}$ & $4.9^{\mathrm{a}}$ & 20.6 & $12.3^{\mathrm{b}}$ & 54.6 & 0.4 & $87.5^{\mathrm{b}}$ \\
& $-\mathrm{HG}^{2}$ & $6.5^{\mathrm{b}}$ & $4.2^{\mathrm{b}}$ & 21.7 & $13.9^{\mathrm{a}}$ & 53.6 & 0.1 & $89.2^{\mathrm{a}}$ \\
Sowing & -300 & $6.6^{\mathrm{b}}$ & 4.4 & 21.2 & 13.6 & 54.1 & 0.1 & 88.9 \\
rate & -600 & $7.2^{\mathrm{a}}$ & 4.6 & 21.7 & 13.0 & 53.2 & 0.3 & 87.9 \\
(pcs/sqm) & -900 & $6.8^{\mathrm{ab}}$ & 4.8 & 20.5 & 12.8 & 55.0 & 0.1 & 88.3 \\
Mineral & -90 & $6.6^{\mathrm{b}}$ & 4.5 & 20.4 & 13.3 & 55.1 & 0.1 & 88.8 \\
fertilization & -180 & $7.1^{\mathrm{a}}$ & 4.7 & 22.0 & 13.0 & 53.1 & 0.1 & 88.1 \\
(kg NPK/ ha) & & & & & & & & \\
SEM & & 0.16 & 0.14 & 0.44 & 0.32 & 0.66 & 0.18 & 0.43 \\
\hline
\end{tabular}

1 - three-way analysis of variance

2 - Hungarian Gold

a. b. - means with different letter are significantly different $(\mathrm{P}<0.05)$; means without index are not significantly different $(\mathrm{P}>0.05)$.

The studied factors had low effect on the content of individual amino acids in the seeds (Table 3). Particularly small differences occurred between cultivars. It was found that except methionine, all the other amino acids were highest in the seeds from plants sown at a rate of $600 \mathrm{pcs} / \mathrm{sqm}$. Increasing the mineral fertilization $(180 \mathrm{vs} .90 \mathrm{~kg}$ $\mathrm{NPK} / \mathrm{ha}$ ) caused an increase in the content of amino acids, especially glutamine, arginine and asparagine $(\mathrm{P}<0.05)$. Literature data revealed few results on amino acid composition of linseed as affected by cultivation factors. The amino acid content varies according to the concentration of protein, which in turn is mainly determined by nitrogen fertilisation and conditions of cultivation (Rodriguez et al., 2001; Treviño et al., 2000; Wanasundara et al., 1999). 
Table 3. Amino acid content $(\mathrm{g} / \mathrm{kg})$ in linseed seeds in relation to sowing rate and mineral fertilization

\begin{tabular}{|c|c|c|c|c|c|c|c|c|}
\hline \multirow{3}{*}{ Amino acids } & & & \multicolumn{5}{|c|}{ Effect $^{1}$} & \multirow{3}{*}{ SEN } \\
\hline & \multicolumn{2}{|c|}{ Cultivars } & \multicolumn{3}{|c|}{ Sowing rate $\mathrm{pcs} / \mathrm{sqm}$} & \multicolumn{2}{|c|}{$\begin{array}{l}\text { Mineral fertilization } \\
\mathrm{kg} \mathrm{NPK} / \mathrm{ha}\end{array}$} & \\
\hline & Opal & $\mathrm{HG}^{2}$ & 300 & 600 & 900 & 90 & 180 & \\
\hline Asp & 19.17 & 19.83 & $18.77^{\mathrm{b}}$ & $20.52^{\mathrm{a}}$ & $19.20^{\mathrm{b}}$ & $18.86^{\mathrm{b}}$ & $20.14^{\mathrm{a}}$ & 0.38 \\
\hline Thr & 7.23 & 7.63 & 7.25 & 7.62 & 7.41 & 7.27 & 7.59 & 0.10 \\
\hline Ser & 9.26 & 9.78 & 9.25 & 9.90 & 9.41 & 9.23 & 9.81 & 0.15 \\
\hline Glu & $38.31^{\mathrm{b}}$ & $39.77^{\mathrm{a}}$ & $38.02^{\mathrm{b}}$ & $40.16^{\mathrm{a}}$ & $38.93^{\mathrm{ab}}$ & $37.87^{\mathrm{b}}$ & $40.20^{\mathrm{a}}$ & 0.55 \\
\hline Pro & 6.24 & 6.94 & 6.37 & 7.24 & 6.15 & 6.22 & 6.96 & 0.24 \\
\hline Gly & 11.70 & 12.16 & 11.63 & 12.27 & 11.89 & 11.62 & 12.24 & 0.17 \\
\hline Ala & 9.56 & 10.20 & 9.62 & 10.24 & 9.80 & 9.54 & 10.22 & 0.17 \\
\hline Val & 10.07 & 10.69 & 10.15 & 10.58 & 10.41 & 10.17 & 10.59 & 0.15 \\
\hline Ile & 8.68 & 9.22 & 8.78 & 9.04 & 8.94 & 8.75 & 9.09 & 0.13 \\
\hline Leu & 11.79 & 12.96 & 12.27 & 12.82 & 12.34 & 12.21 & 12.75 & 0.19 \\
\hline Tyr & 5.35 & 5.82 & 5.54 & 5.71 & 5.50 & 5.48 & 5.69 & 0.09 \\
\hline Phe & 9.46 & 9.73 & 9.43 & 9.84 & 9.51 & 9.36 & 9.83 & 0.12 \\
\hline His & 5.47 & 5.76 & 5.51 & 5.73 & 5.53 & 5.48 & 5.70 & 0.07 \\
\hline Lys & 7.51 & 8.51 & 7.90 & 8.18 & 7.96 & 7.89 & 8.13 & 0.16 \\
\hline Arg & 21.35 & 22.04 & 21.05 & 22.43 & 21.60 & $21.01^{\mathrm{b}}$ & $22.38^{\mathrm{a}}$ & 0.34 \\
\hline Cys & 3.19 & 3.26 & 3.22 & 3.31 & 3.15 & 3.13 & 3.32 & 0.05 \\
\hline Met & 3.19 & 3.13 & 3.23 & 3.21 & 3.04 & 3.09 & 3.23 & 0.10 \\
\hline -way analysi & f varia & & & & & & & \\
\hline arian Gold & & & & & & & & \\
\hline
\end{tabular}

Regardless of the cultivation factors studied, cv. Opal was characterized by an nearly equal seed yield per ha (1844 vs. $1809 \mathrm{~kg} / \mathrm{ha}$; Figure 1) compared to cv. HG. Zając et al. (2001) underline that yielding of linseed cultivars, which differed in their seed colour, is very similar and depends mainly on two structural traits, i.e. shoot density and the weight of 1000 seeds. Increasing the level of mineral fertilization from 90 to $180 \mathrm{~kg}$ $\mathrm{NPK} / \mathrm{ha}(30$ vs. $60 \mathrm{~kg} \mathrm{~N} / \mathrm{ha}$ ) caused an increase in the yield of seeds by $6.1 \%(\mathrm{P}<0.05)$. However, such an increment of yield is not very efficient and fails to compensate for the costs of fertilization. On the other hand Grant et al. (1999) using three nitrogen doses of 10, 40 and $80 \mathrm{~kg} \mathrm{~N} / \mathrm{ha}$ achieved the highest yield of seeds with the medium dose of $40 \mathrm{~kg} \mathrm{~N} / \mathrm{ha}$. When the dose was higher $(80 \mathrm{~kg} \mathrm{~N} / \mathrm{ha})$, increased lodging was observed. When lodging occurred, i.e. already in the blooming period, it restricted the seed yield of the three linseed cultivars studied.

The yield of main nutrients remained at a similar level and averaged for $790 \mathrm{~kg} / \mathrm{ha}$ for fat and $370 \mathrm{~kg} / \mathrm{ha}$ for protein. The most beneficial effect of nutrients on the yield was exerted by sowing at $600 \mathrm{pcs} / \mathrm{sqm}$. Also increasing the mineral fertilization from 90 to $180 \mathrm{~kg} \mathrm{NPK} / \mathrm{ha}$ had a positive effect on the yield of seeds, fat and protein. These results indicate, however, that cultivation factors had little influence on the protein and fat yield. The yields of the Polish brown-seeded cultivar Opal and the Hungarian yellow-seeded cultivar Hungarian Gold were similar, indicating a low effect of the cultivar factor. On the other hand, the content of fibre, especially acid detergent lignin (ADL) in the seeds, was much higher in cv. Opal. Both, the application of a medium sowing rate of linseed (600 pcs/sqm) and mineral fertilization at a rate of $180 \mathrm{~kg} \mathrm{NPK} / \mathrm{ha}$ ensured the highest yields of seeds, protein and fat. 
$\square$ seed yield $\quad \mathbf{\square}$ fat yield $\quad \square$ crude protein yield

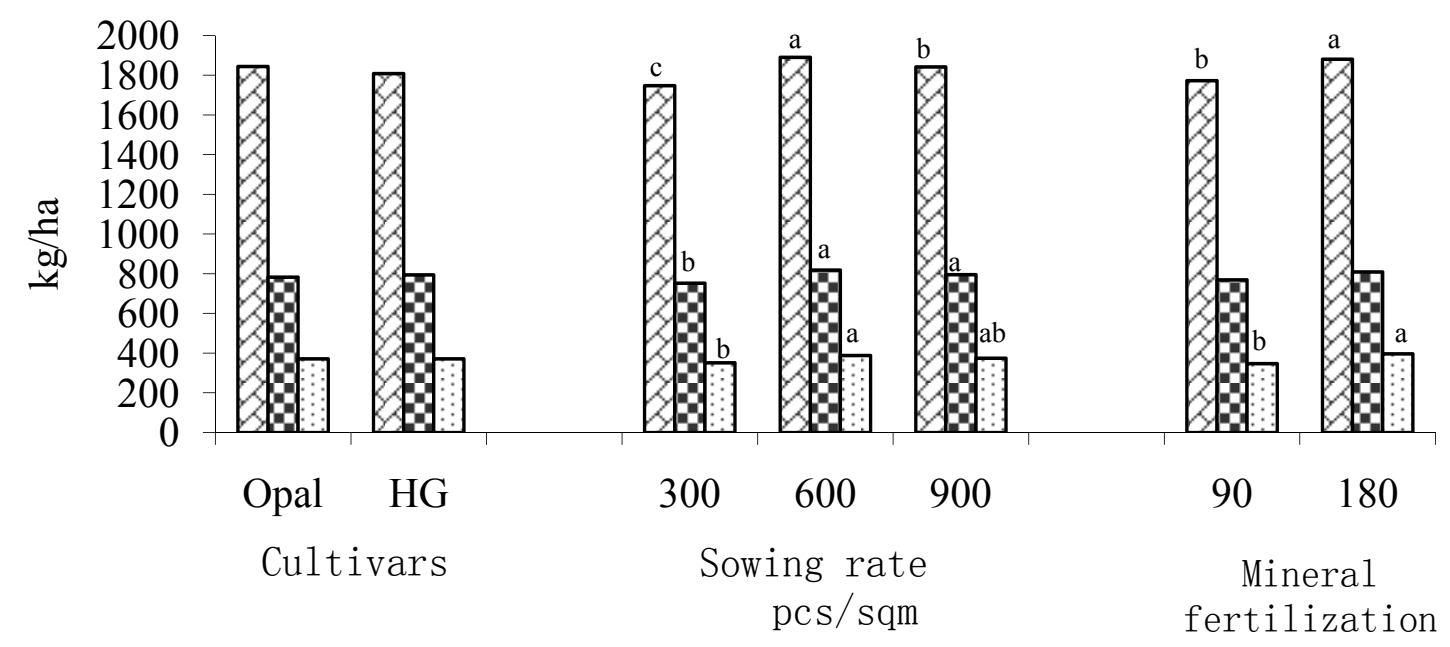

Figure 1. The forming of seed, fat and crude protein yield $(\mathrm{kg} / \mathrm{ha})$ of linseed cultivars in relation to sowing rate and mineral fertilization

a. b. - means with different letter are significantly different $(\mathrm{P}<0.05)$.

\section{Conclusions}

Linseed cultivars of different colour did not show important differences in chemical composition of the seeds resulting from the application of different levels of mineral fertilization and different sowing rates. However, the average sowing rate of 600 pieces per $\mathrm{m}^{2}$ may be recommended.

\section{References}

AOAC. (1995). Official Methods of Analysis of the Association of Official Analytical Chemists (16th Edition). Arlington, Virginia (USA).

Barowicz, T. (1998). Effect of dietary fat on lipid quality in animal tissues and products of animal origin. Biul. Inf. IZ., XXXVI, 3, 39-48 (in Polish).

Borowiec, F., Zając, T., Kowalski, Z. M., Micek, P., \& Marciński, M. (2001). Comparison of nutritive value of some new commercial linseed oily cultivars for ruminants. J. Anim. Feed Sci., 10, 301-308.

Candrakova, E., \& Bakula, J. (2001). Influence of nitrogen fertilization on morphological characters, yieldforming components and seed yield of oilseed flax. Acta Fytotech. Zootech., 1, 9-12 ( In Slovak).

Casa, R., Russell, G., Lo Cascio, B., \& Rossini, F. (1999). Environmental effects on linseed (Linum usitatissimum L.) yield and growth of flax at different stand densities. Eur. J. Agron., 11, 267-278. http://dx.doi.org/10.1016/S1161-0301(99)00037-4

Diepenbrock, W. (2001). Crop physiology of oilseeds: a comparative analysis between rapeseed (Brassica napus L.), sunflower (Helianthus annuus L.), and linseed (Linum usitatissimum L.). Scientia Agric. Bohemica, 32(4), 323-339.

Dribnenki, J. C. P., McEachern, S. F., Green, A. G., Kenaschuk, E. O., \& Rashid, K. Y. (1999). Linola ${ }^{\text {TM }} 1084$ low linolenic acid flax. Can. J. Plant Sci., 79, 607-609. http://dx.doi.org/10.4141/P99-053

Froment, M. A., Smith, J. M., \& Turley, D. (1998). Fatty acids profiles in the seed oil of linseed and fibre flax cultivars (Linum usitatissimum L. ) grown in England and Scotland. Tests of Agrochemicals and Cultivars No. 19. Ann. Appl. Biol., 132(supplement), 60-61.

Goering, H. K., \& Van Soest, P. J. (1970). Forage Fiber Analyses (Apparatus, Reagents, Procedures, and Some Applications). Agric. Handbook No. 379 (pp. 1-20). Washington, DC: ARS-USDA. 
Grant, C. A., Dribnenki, J. C. P., \& Bailey, L. D. (1999). A comparison of the yield response of solin (cv. Linola 947) and flax (cvs. McGregor and Vimy) to applications of nitrogen, phosphorus, and Provide (Penicillium bilaji). Can. J. Plant Sci., 79, 527-533. http://dx.doi.org/10.4141/P98-085

Hassan, F. U., \& Leitch, M. H. (2000). Influence of seeding on contents and uptake of N, P and K in linseed

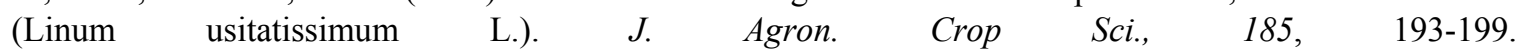
http://dx.doi.org/10.1046/j.1439-037x.2000.00427.x

Hocking, P. J. (1995). Effects of nitrogen supply on the growth, yields components and distribution of nitrogen in Linola. J. Plant Nutr., 18, 257-275. http://dx.doi.org/10.1080/01904169509364899

Rodriguez, M. L., Alzueta, C., Rebolé, A., Ortiz, L. T., Centeno, C., \& Treviño, J. (2001). Effect of inclusion level of linseed on the nutrient utilization of diets for growing broiler chickens. Brit. Poultry Sci., 42, 368-375. http://dx.doi.org/10.1080/00071660120055359

Saeidi, G., \& Rowland, G., G. (1999). Seed colour and linolenic acid effects on agronomic traits in flax. Can. J. Plant Sci., 79, 521-526. http://dx.doi.org/10.4141/P99-019

SAS. (1995). SAS/STAT ${ }^{\circledR}$ Users Guide (Release 6.03). Cary, NC: SAS Inst. Inc.

Treviño, J., Rodriguez, M. L., Ortiz, L.T., Rebolé, A., \& Alzueta, C. (2000). Protein quality of linseed for growing broiler chicks. A. Feed Sci. Tech., 84, 155-166. http://dx.doi.org/10.1016/S0377-8401(00)00128-0

Wanasundara, P. K. J. P. D., Shahidi, F., \& Brosnan, M. E. (1999). Changes in flax (Linum usitatissmum) seed nitrogenous compounds during germination. Food Chem., 65, 289-295. http://dx.doi.org/10.1016/S0308-8146(98)00176-9

Zając, T., Borowiec, F., \& Micek, P. (2001). Comparison of productivity, chemical composition and fatty acid profile of yellow and brown linseeds. Rośliny Oleiste Oilseed Crops, XXII, 441-453 (in Polish).

Zubal, P. (2001). The effects of sowing date, seeding rate and nutrition on yields of the oilseed flax cultivars (Linum usitatissimum L.). Ved. Prace Vysk. Ust. Rastl. Vyr., 30, 33-38. 